\title{
Rice-Straw-Based Heat Generation System Compared to Open-Field Burning and Soil Incorporation of Rice Straw: An Assessment of Energy, GHG Emissions, and Economic Impacts
}

\author{
Maria Victoria P. Migo-Sumagang ${ }^{1,2, *}$, Monet Concepcion Maguyon-Detras ${ }^{2}$, Martin Gummert ${ }^{1}$, \\ Catalino G. Alfafara ${ }^{2}$, Myra G. Borines ${ }^{2}$, Jewel A. Capunitan ${ }^{2}$ and Nguyen Van Hung $1, *$ (i) \\ 1 International Rice Research Institute, DAPO Box 7777, Metro Manila, Manila 1301, Philippines; \\ m.gummert@irri.org \\ 2 Department of Chemical Engineering, College of Engineering and Agro-Industrial Technology, \\ University of the Philippines Los Baños, College, Los Baños, Laguna 4031, Philippines; \\ mmdetras@up.edu.ph (M.C.M.-D.); cgalfafara@up.edu.ph (C.G.A.); mgborines@up.edu.ph (M.G.B.); \\ jacapunitan@up.edu.ph (J.A.C.) \\ * Correspondence: mpmigo@up.edu.ph (M.V.P.M.-S.); hung.nguyen@irri.org (N.V.H.)
}

Received: 1 June 2020; Accepted: 24 June 2020; Published: 1 July 2020

\begin{abstract}
Rice is a staple food crop, and its production generates large volumes of agricultural waste, rice straw. Several studies have proven that open-field burning and soil incorporation are unsustainable practices of managing rice straw, but remain as prevalent methods of treating and disposing of rice straw. An alternative solution is to harness the energy from rice straw via a small-scale heat conversion system for paddy drying applications, which can reduce rice grain post-processing costs and improve paddy storage conditions. This study investigated the energy flow, Greenhouse Gas (GHG) emissions, and cost of a small-scale rice-straw-based heat generation (RBHG) system using a downdraft furnace and a dryer simulator setup. The highest input energy and GHG emissions of $92 \%$ and $68 \%$, respectively, were from the heat generation stage. The RBHG energy ratio was between 1.4 and 1.7 , and the percent net energy was between 39 and $67 \%$. The best case of RBHG offers a possibility of a net GHG avoided (-61 $\mathrm{kg} \mathrm{CO}_{2}$-eq $\left.\mathrm{Mg}^{-1}\right)$, while the worst case (856 $\mathrm{kg} \mathrm{CO}_{2}$-eq $\mathrm{Mg}^{-1}$ ) has a net $\mathrm{GHG}$ emission comparable with soil incorporation. The average total cost of RBHG is $0.096 \mathrm{USD} \mathrm{kWh}^{-1}$. Overall, RBHG technology has the potential to improve energy flow, GHG emissions, and the cost of rice production systems.
\end{abstract}

Keywords: rice straw; bioenergy; furnace; net energy balance; Net GHG emissions; Life Cycle Assessment

\section{Introduction}

Rice is one of the most staple foods in the world, providing the calorie requirement of many countries. As one of the leading food crops, its production reached up to 780 million Mg globally in 2018, covering 167 hectares of land [1]. The leading producers are Asian countries, with China, India, and Indonesia in the top three [1]. The Philippines, like its neighboring countries, primarily depends on rice as its main food source, with $80 \%$ of the population relying on rice for $40-65 \%$ of their calorie requirement [2].

The steady increase in the cultivation of rice for food rice production has given rise to the problem of rice straw waste management. About 1 to 1.5 megagrams of rice straw are produced for every megagram of paddy [2-4]. In many rice-growing countries, the most common rice straw waste 
management method is open-field burning [5-11]. In the Philippines, farmers turn to open-field burning to drive away pests and to avoid the labor-intensive, manual gathering of rice straw [2,7]. In $2009,95 \%$ of the total surplus of $10,150 \mathrm{Mg}$ rice straw in the country was managed or disposed of by open-field burning [12]. Though the burning of biomass may be considered a carbon-neutral activity, it also causes the emission of toxic greenhouse gases $\mathrm{CH}_{4}$ and $\mathrm{N}_{2} \mathrm{O}[7,12]$. Open-field burning also results in up to $100 \%$ nitrogen $(\mathrm{N})$ loss, $25 \%$ phosphorous $(\mathrm{P})$ loss, $20 \%$ potassium (K) loss, and $5-60 \%$ sulfur loss [7].

A common alternative to open-field burning is soil incorporation, or leaving the straw on the field to decompose $[5,13]$. The benefits of soil incorporation include a complete carbon turnover, improved soil aeration, re-oxidation of iron and other reduced substances (which accumulate during flooding), reduced weed growth, and reduced irrigation requirement [14]. However, these benefits may be offset by the disadvantages of soil incorporation, which include the risk of decreased grain yield, acetic acid formation, decrease in available nitrogen, and insufficient turnaround time for intensive cropping systems $[14,15]$. Moreover, soil incorporation leads to a higher global warming potential (GWP) at $8023 \mathrm{~kg} \mathrm{CO}$-eq per ha, higher than open-field burning, which is at $4913 \mathrm{~kg} \mathrm{CO}$-eq per ha [7]. Yield-scaled GWP measurements for complete soil incorporation, partial straw removal, complete straw removal, and complete straw burning scenarios were found to be $881,477,174,453 \mathrm{~kg} \mathrm{CO} \mathrm{CO}_{2-}$ per $\mathrm{Mg}$ straw, respectively [7]. In other studies, open-field burning was evaluated to cause 1460 $\mathrm{kg} \mathrm{CO}$-eq per $\mathrm{Mg}$ straw [6], and soil incorporation results to $1025 \mathrm{~kg} \mathrm{CO}$-eq per $\mathrm{Mg}$ straw [13]. These numbers highlight the comparative advantage of complete straw removal (over other scenarios mentioned), as it had the lowest GWP. After complete removal from the field, rice straw can be further processed under several alternatives.

\subsection{Complete Straw Removal and the Paddy Flatbed Dryer (PFBD)}

Complete straw removal from the field provides the opportunity for other off-field uses of rice straw. The other off-field rice straw management options are divided into energy solutions (direct combustion, bioethanol, and anaerobic digestion) and non-energy solutions (substrate for mushroom production, animal bedding, and fodder, biochar, and fertilizer) [3,5,6]. Among the different off-field solutions, rice-straw-based heat generation using direct combustion furnaces is one of the simplest. The heat generated may be used to dry rice paddy in a paddy dryer. There are different types of paddy dryers, but a paddy flatbed dryer (PFBD) composed of a drying bin, blower, and furnace is preferable due to its simplicity and low cost [16]. In a PFBD, hot air mixture from the furnace is directed by the blower to the grain bed, increasing the drying bin temperature to $43-45^{\circ} \mathrm{C}$. The drying time is around $4-10 \mathrm{~h}$ depending on the temperature and initial moisture content, the common capacity is 4-6 tons paddy per batch, while the working hours may be 16 to $20 \mathrm{~h}$ per day in a 40 -day harvest season [16]. The motor may be diesel- or electric-powered, with a horsepower rating of 7-12 HP [16].

Currently, PFBD furnaces use kerosene or rice husk as fuel. Kerosene is a nonrenewable resource from petroleum, while rice husk is a renewable resource from rice production. Compared to rice straw, rice husk is lesser in supply but higher in demand. An existing small-scale downdraft furnace (dRF) using direct combustion technology at the International Rice Research Institute (IRRI) uses rice husk as fuel, with drying air efficiencies reaching about $80 \%$ maximum. In a related study, the IRRI $\mathrm{dRF}$ was retrofitted to use rice straw instead of rice husk. The optimum operating conditions for this dryer (retrofitted for rice straw feed) have recently been determined. The drying air efficiencies at the optimum conditions were between 86.1 and $88.78 \%$ [17].

To have a more meaningful comparison of the different alternatives for rice straw waste management concerning energy and sustainability, various studies have performed life cycle assessment (LCA). 


\subsection{Life Cycle Assessment in Rice Production}

In rice production, the steps in the supply chain are rice cultivation, harvesting, collection, transportation, storage, and utilization of rice straw [8]. In assessing the life cycle of biofuels, the complete cycle from raw material production, processing transportation, manufacturing, storage, distribution, and utilization should be considered as each step may have a negative or positive impact on the environment, economy, or social aspects [18]. Despite the "cradle-to-grave" principle of life cycle assessment, for bioenergy studies, an arbitrary system boundary may be defined as many processes are excluded for different reasons [18]. Instead of the "cradle-to-grave," the "cradle-to-gate" approach is sufficient for comparing different biofuel production processes [18].

\subsection{Rationale of the Study}

Using rice straw as fuel in paddy drying will help in averting open-field burning, as well as support the rising energy demand. At $100 \%$ collection, the renewable energy potential from rice straw can reach up to 141,800 GJ in the Philippines [12]. Studies on rice-straw-based power generation in Malaysia, Thailand, India, and Egypt show reduced Greenhouse gas (GHG) emissions and other environmental benefits $[6,9,11,13,19]$. Input-output energy analysis in Iran and China reports an energy ratio between 1.39 and 9.94 with both paddy and straw values in the output energies [20,21]. For small communities, a small-scale rice-straw-based heat generation system with an energy output between 100 and $300 \mathrm{MJ} \mathrm{h}^{-1}$ may be advantageous since it requires lower capital and transportation costs. A process bottleneck is found in the rice straw collection step, which is known to be labor-intensive if done manually. The other option, mechanical collection, requires high capital costs due to the use of a baler. Thus, an alternative to offer baling as a service to generate profit may improve the costs.

This study was conducted to assess the energy flow as well as the net GHG emissions of a small-scale rice-straw-based heat generation (RBHG) system for paddy drying. The cost per heat output using the IRRI downdraft furnace (dRF) was also evaluated. The results of this research aim to help in the decision and policymaking on the sustainability of rice straw waste management systems.

\section{Materials and Methods}

\subsection{Research Study Area and System Boundaries}

The research was conducted at the International Rice Research Institute (IRRI), and the data used was from the IRRI and Philippine farmer fields.

The system boundaries for both energy balance and GHG emissions are shown in Figure 1 for rice-straw-based heat generation (RBHG). There are four (4) stages: rice production at IRRI and Philippine farmer fields during the dry season, baled straw collection and transportation to a storage area $4 \mathrm{~km}$ away, rice straw storage in a roofed facility, and rice-straw-based heat generation using the downdraft furnace (dRF) with electric motor and blower. The three (3) initial stages can be grouped as the rice straw preparation stage. In each step, the inputs and outputs are listed; for example, in rice production, diesel consumption in agricultural equipment, rice seeds, fertilizers, pesticides/herbicides, manual labor, and land use are all inputs, while the outputs are rice straw (on the field), and rice paddy. The rice straw output from rice production is considered as input in the next stage, the rice straw collection and transportation stage. The functional unit for the energy flow and GHG emission balance is $1 \mathrm{Mg}$ rice straw as fuel. The functional unit for the cost evaluation is $1 \mathrm{kWh}$ of heat output as a product. 


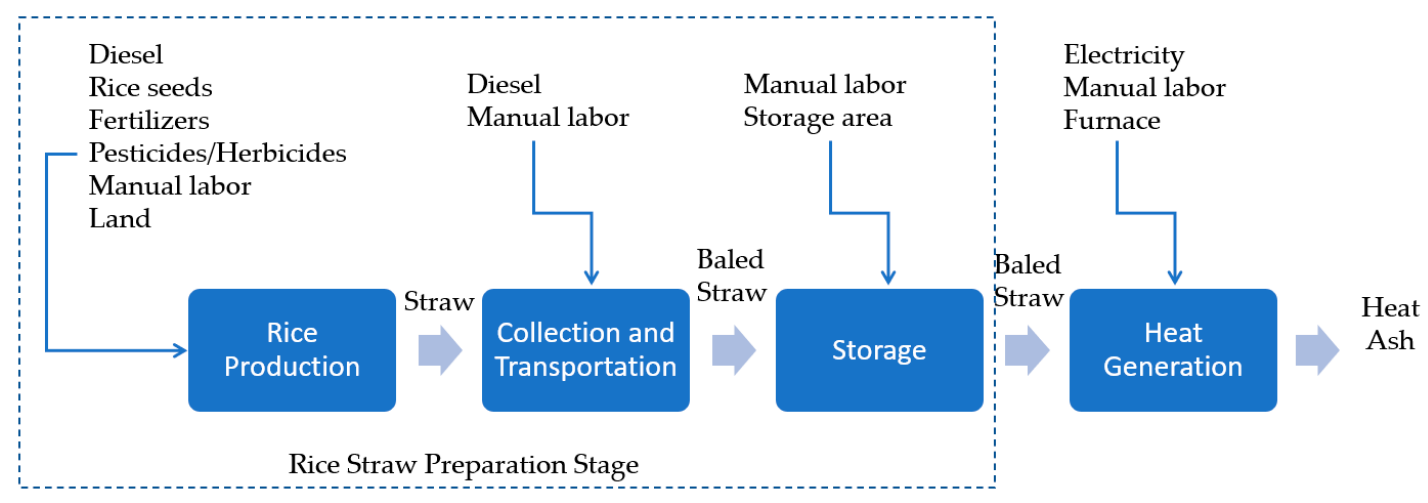

Figure 1. System boundaries for rice-straw-based heat generation (RBHG).

\subsection{Data Collection}

\subsubsection{Assessment of the Structures}

The construction of the storage center and downdraft furnace (dRF), which are referred to in this study as structures, were assessed through interviews with a civil engineer and furnace fabricator. The storage center was a roofed facility with a $200 \mathrm{sq}$. meter floor area, $3 \mathrm{~m}$ high, and open sides. The bill of quantities (BOQ), electricity consumption, and manual labor during construction of the two structures are listed in Table 1 . The dRF included the electric motor and blower.

Table 1. Bill of quantities (BOQ), electricity consumption, and manual labor during construction of one (1) unit of structure.

\begin{tabular}{ccc}
\hline Parameter & Unit & Quantity \\
\hline Storage center structure & & \\
Alkyd paint & $\mathrm{kg}$ & 42 \\
Cement cast plaster & $\mathrm{kg}$ & 1082 \\
Cement, Portland & $\mathrm{kg}$ & 18,636 \\
Concrete block & $\mathrm{kg}$ & 42,000 \\
Gravel & $\mathrm{kg}$ & 44,016 \\
Plywood & $\mathrm{m}^{3}$ & 0.12 \\
Polyvinyl Chloride (PVC) pipe & $\mathrm{kg}$ & 6 \\
Reinforcing steel & $\mathrm{kg}$ & 1681 \\
Sand & $\mathrm{kg}$ & 39,954 \\
Steel sheet & $\mathrm{kg}$ & 1616 \\
Kg & 6 \\
Steel, low-alloyed, hot-rolled & $\mathrm{m}$ & 640 \\
Welding, arc, steel & $\mathrm{kWh}$ & 1000 \\
Electricity & $\mathrm{MJ}$ & 4576 \\
Manual labor construction & & \\
Downdraft furnace (dRF) structure & $\mathrm{kg}$ & 250 \\
Cement, Portland & $\mathrm{kg}$ & 385 \\
Clay brick & $\mathrm{kg}$ & 73 \\
Electric motor & $\mathrm{kg}$ & 324.03 \\
Reinforcing steel & $\mathrm{kg}$ & 155.05 \\
Steel sheet & $\mathrm{kg}$ & 1 \\
Steel, low-alloyed, hot-rolled & $\mathrm{kg}$ & 1 \\
Synthetic rubber & $\mathrm{m}$ & 319.99 \\
Welding, arc, steel & $\mathrm{kWh}$ & 78.8 \\
Electricity & $\mathrm{MJ}$ & 192 \\
Manual labor & &
\end{tabular}




\subsubsection{Rice Straw Preparation}

Data on rice production, collection, and transportation are found in Table $2[7,8,22]$. During rice production, the diesel consumption of machinery from the references included the rotovator, tiller, spreader, thresher, and combine harvester. Some references also included manual labor from a draught animal. Rice paddy yield (varieties: NSIC Rc222, Rc18-38\%, Rc222-33\%, IR74-6\%, NSIC Rc18) was at an average of $4.8 \mathrm{Mg} \mathrm{ha}^{-1}$ with a range of $3.31-6.70 \mathrm{Mg} \mathrm{ha}^{-1}$; while rice straw yield was at an average of $2.69 \mathrm{Mg} \mathrm{ha}^{-1}$ with a range of $2.23-3.39 \mathrm{Mg} \mathrm{ha}^{-1}[7,22,23]$.

Table 2. Published agronomic inputs in dry season rice straw preparation.

\begin{tabular}{cccc}
\hline Parameter & Range & Average & Sources \\
\hline $\begin{array}{c}\text { Rice production } \\
\text { Seeds }\left(\mathrm{kg} \mathrm{ha}^{-1}\right)\end{array}$ & $20-100$ & 50 & {$[7,22,23]$} \\
Fertilizer $\left(\mathrm{kg} \mathrm{ha}^{-1}\right)$ & & & \\
$\mathrm{N}$ & $58-195$ & 125 & {$[7,22,23]$} \\
$\mathrm{P}_{2} \mathrm{O}_{5}$ & $15-50$ & 25 & {$[7,22,23]$} \\
$\mathrm{K}_{2} \mathrm{O}$ & $8.4-30$ & 21 & {$[7,22,23]$} \\
Herbicide $\left(\mathrm{kg} \mathrm{ha}^{-1}\right)$ & $0.75-1.98$ & 1.24 & {$[22,23]$} \\
Insecticide $\left(\mathrm{kg} \mathrm{ha}^{-1}\right)$ & $0.50-2.87$ & 1.45 & {$[22,23]$} \\
Total diesel consumption of machineries $\left(\mathrm{L} \mathrm{ha}^{-1}\right)$ & $32-145$ & 82 & {$[22,23]$} \\
Total manual labor $\left(\mathrm{MJ} \mathrm{ha}^{-1}\right)$ & $423-820$ & 618 & {$[22,23]$} \\
Rice straw collection and transportation & & & \\
Total diesel consumption of machineries $\left(\mathrm{L} \mathrm{Mg}^{-1}\right)$ & $4.79-14.10$ & 8.30 & {$[8]$} \\
Total manual labor $\left(\mathrm{MJ} \mathrm{Mg}^{-1}\right)$ & $0.97-2.43$ & 1.19 & {$[8]$} \\
\hline
\end{tabular}

The data for mechanical collection and transportation to a storage area $(4 \mathrm{~km}$ away from the collection area) were also based on reference studies shown in Table 2. Diesel consumption during this stage included machinery, tractor, and trailer. The manual labor during this stage included rice straw handling and driving of the machinery. On the other hand, the manual labor capacity during rice straw storage was determined by measuring the weight of rice straw handled during storage per unit time (in three replicates).

\subsection{RBHG Experiments}

The rice straw samples used for heat generation in the dRF were collected from the rice production (variety NSIC Rc 238) during the dry seasons of 2017 and 2018 at IRRI, which used an alternate wetting and drying water management and a cropping duration of 110 days. A square baler (CLAAS Markant 55, $45 \mathrm{HP}$ ) attached to a tractor (MF399, 5.8 L, 6-cylinder diesel engine) was used for baled straw collection. The moisture contents of the sun-dried rice straw samples were measured using ASAE Standard S358.2 (DEC93) Moisture Measurement for Forages Method, which ranged from 8.89 to $10.48 \%$.

The combustion setup was based on initial experiments conducted at IRRI on the dRF using rice straw as fuel [17]. The dRF was attached to a pre-calibrated dryer simulator $(7.82 \mathrm{~m}$ long and $0.7 \mathrm{~m}$ in diameter) where temperature and percent relative humidity measurements were made. The blower connected to an electric motor (TECO 3-Phase Induction Motor Type AEEF-F-YC4, 1750 RPM, 10 HP) was controlled via an automatic controller (Schneider Electric variable speed drive ATV312HD11M3 3-phase supply) attached to a power monitor (Efergy Electricity Monitoring Transmitter). The drying airflow rate was set by adjusting the cone in the dryer simulator, as well as setting the frequency of the automatic controller. Two $\mathrm{kg}$ of rice straw were loaded initially into the primary combustion chamber via the feed hopper. A blowtorch was used to ignite the first rice straw via the bottom ash exit, and the rice straw feed rate was manually set by weight over time measurements.

Two scenarios of optimized conditions of rice straw feed rate (SFR) and drying air flow rate (DAF) were tested based on a previous study [17]. Based on the study, Scenario 1 (using SFR: $28.06 \mathrm{~kg} \mathrm{~h}^{-1}$, DAF: $4 \mathrm{~m}^{3} \mathrm{~s}^{-1}$ ) resulted in a dRF heat output, $\mathrm{CO}$, and NOX emissions of $332.48 \mathrm{MJ} \mathrm{h}^{-1}, 89.9 \mathrm{ppm}$, 


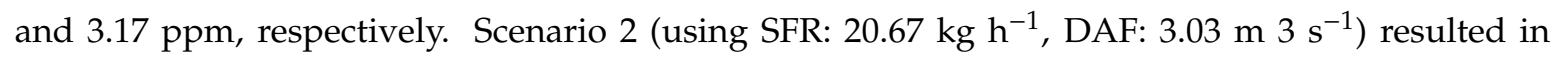
a dRF heat output, $\mathrm{CO}$, and NOX emissions of $231.47 \mathrm{MJ} \mathrm{h}^{-1}, 76.57 \mathrm{ppm}$, and $2.93 \mathrm{ppm}$, respectively. The electricity consumption of the blower in $\mathrm{kW}$ was monitored every $5 \mathrm{~min}$ through the power monitor. The bottom ash was collected and weighed after every run. The dRF operation labor capacity was determined by measuring the weight of rice straw and manual labor time in three replicates.

\subsection{Methodology and Software Used for Calculation and Simulation}

Rice production was allocated between the two products in terms of economic value [19] to remove the influence of rice paddy in the output. The allocation was only applied in the rice production stage since rice straw was the sole product in the next stages (rice straw collection and transportation). Equations (1) and (2) were used in the economic allocation $[8,24,25]$.

$$
\begin{gathered}
\% \text { Allocation of rice straw }=100 * \mathrm{Y}_{\mathrm{rs}} * \mathrm{P}_{\mathrm{rs}} /\left(\mathrm{Y}_{\mathrm{pd}} * \mathrm{P}_{\mathrm{pd}}+\mathrm{Y}_{\mathrm{rs}} * \mathrm{P}_{\mathrm{rs}}\right) \\
\% \text { Allocation of paddy }=100-\text { Allocation of rice straw }
\end{gathered}
$$

where $Y_{r s}$ is the yield of rice straw, $P_{r s}$ is the price of rice straw based on calculations in this study, $\mathrm{Y}_{\mathrm{pd}}$ is the yield of paddy, and $\mathrm{P}_{\mathrm{pd}}$ is the price of paddy at $430 \mathrm{USD} \mathrm{Mg}^{-1}$ [26] based on an exchange rate of 1 USD $=52.10$ PHP [27]. The total rice production input in Table 3 was multiplied with the percent allocation for rice straw in both energy and GHG emissions.

Table 3. Calculated energy and Greenhouse gas (GHG) emissions during rice production (without

\begin{tabular}{|c|c|c|}
\hline Parameter & $\begin{array}{c}\text { Energy } \\
\mathrm{MJ} \mathrm{Mg}^{-1}\end{array}$ & $\begin{array}{l}\text { GHG Emissions } \\
\mathrm{kg} \mathrm{CO}_{2} \text {-eq } \mathrm{Mg}^{-1}\end{array}$ \\
\hline \multicolumn{3}{|l|}{ INPUTS } \\
\hline \multicolumn{3}{|l|}{ Rice production } \\
\hline Mechanized operations & $867-2583$ & $80-238$ \\
\hline Labor & 190-242 & \\
\hline Rice seeds & $241-794$ & $15.3-50.4$ \\
\hline Fertilizer & $1714-3973$ & $159-352$ \\
\hline Herbicide & $101-176$ & $5.7-9.9$ \\
\hline Insecticide & 53-199 & $2.9-10.9$ \\
\hline Subtotal, rice production & $3166-7967$ & $263-661$ \\
\hline \multicolumn{3}{|l|}{ Rice straw collection and transportation } \\
\hline Mechanized operations & $130-251$ & $12-23$ \\
\hline Labor & $0.97-2.43$ & \\
\hline Subtotal, rice straw collection and transportation & $131-254$ & $12-23$ \\
\hline Direct soil emissions from partial or complete straw removal & & $174-477$ \\
\hline
\end{tabular}
allocation), rice straw collection, and transportation using secondary data.

The energy conversion for manual labor was based on the metabolic equivalent of task (MET) or the ratio of human metabolic rate when performing a task to the metabolic rate during rest [23]. Manual handling of rice straw with an energy output of $0.89 \mathrm{MJ} \mathrm{h}^{-1}[8,23]$ was assumed for rice straw storage and dRF operation.

The method Cumulative Energy Demand version 1.10 was used for the conversion of the agronomic inputs to energy, through the SimaPro software, version 8.0.5.13 [28]. The software automatically multiplies all the agronomic inputs by their corresponding energy equivalents in Table 4 . The calculated energies during rice production, rice straw collection, and transportation using secondary data are found in Table 3. 
Table 4. Energy equivalent and GHG emission factors of inputs and outputs.

\begin{tabular}{|c|c|c|c|c|}
\hline Parameter & Unit & $\begin{array}{l}\text { Energy Equivalent } \\
\left(\mathrm{MJ} \mathrm{unit}^{-1}\right)\end{array}$ & $\begin{array}{l}\text { GHG Emission Factor } \\
\left(\mathrm{kg} \mathrm{CO}_{2} \text {-eq unit }{ }^{-1}\right)\end{array}$ & Sources \\
\hline \multicolumn{5}{|l|}{ INPUTS/GHG EMISSIONS } \\
\hline Diesel consumption & $\mathrm{L}$ & 44.8 & 4.13 & [29-32] \\
\hline Machine manufacture & $\mathrm{L}$ & 15.6 & 1.44 & [30-33] \\
\hline Labor & $\mathrm{h}$ & 0.89 & & [23] \\
\hline Seeds & $\mathrm{kg}$ & 26.91 & 1.71 & {$[29,32]$} \\
\hline Nitrogen & $\mathrm{kg}$ & 60 & 5.75 & {$[29,32]$} \\
\hline $\mathrm{P}_{2} \mathrm{O}_{5}$ & $\mathrm{~kg}$ & 17.81 & 1.12 & {$[29,32]$} \\
\hline $\mathrm{K}_{2} \mathrm{O}$ & $\mathrm{kg}$ & 8.94 & 0.53 & {$[29,32]$} \\
\hline Herbicide & $\mathrm{kg}$ & 300.63 & 16.87 & {$[29,32]$} \\
\hline Insecticide & $\mathrm{kg}$ & 301.55 & 12.84 & {$[29,32]$} \\
\hline \multicolumn{5}{|c|}{ Structure materials and energy } \\
\hline Alkyd paint & $\mathrm{kg}$ & 99.52 & 6.74 & {$[29,32]$} \\
\hline Cement, Portland & $\mathrm{kg}$ & 4.28 & 0.94 & {$[29,32]$} \\
\hline Concrete block & $\mathrm{kg}$ & 0.86 & 0.09 & {$[29,32]$} \\
\hline Clay brick & $\mathrm{kg}$ & 3.84 & 0.32 & {$[29,32]$} \\
\hline Sand & $\mathrm{kg}$ & 0.19 & 0.01 & {$[29,32]$} \\
\hline Gravel & $\mathrm{kg}$ & 0.19 & 0.012 & {$[29,32]$} \\
\hline Cement cast plaster & $\mathrm{kg}$ & 1.37 & 0.21 & {$[29,32]$} \\
\hline Plywood & $\mathrm{m}^{3}$ & 43,613 & 660.93 & {$[29,32]$} \\
\hline PVC Pipe & $\mathrm{kg}$ & 68 & 3.4 & {$[32,34]$} \\
\hline Reinforcing steel & $\mathrm{kg}$ & 23.63 & 2.04 & {$[29,32]$} \\
\hline Steel sheet & $\mathrm{kg}$ & 33.27 & 2.9 & {$[32,34]$} \\
\hline Steel, low-alloyed, hot-rolled & $\mathrm{kg}$ & 24 & 2.2 & {$[29,32]$} \\
\hline Welding arc, steel & $\mathrm{m}$ & 2.63 & 0.21 & {$[29,32]$} \\
\hline Electric motor & unit & 6850 & 537 & {$[29,32]$} \\
\hline Synthetic rubber & $\mathrm{kg}$ & 87.7 & 2.88 & {$[29,32]$} \\
\hline Electricity & MJ & 3.11 & 0.21 & {$[29,32]$} \\
\hline Labor & $\mathrm{h}$ & 1.0 & & [35] \\
\hline \multicolumn{5}{|l|}{ Rice Straw Combustion } \\
\hline $\mathrm{CH}_{4}$ & $\mathrm{~kg}$ & & 30.5 & [29] \\
\hline $\mathrm{N}_{2} \mathrm{O}$ & $\mathrm{kg}$ & & 265 & [29] \\
\hline \multicolumn{5}{|l|}{ OUTPUTS/GHG AVOIDED } \\
\hline dRF heat output & MJ & 1 & & \\
\hline Kerosene substitute & GJ & & 71 & {$[36,37]$} \\
\hline Ash as concrete aggregate substitute & $\mathrm{kg}$ & 0.19 & 0.012 & {$[29,32]$} \\
\hline
\end{tabular}

For the GHG emissions balance, the method IPCC 2013 GWP 100a version 1.03 [28] was used for the conversion of the agronomic inputs to $\mathrm{kg} \mathrm{CO}_{2}$-eq based on their GHG emission factors in Table 4 . Direct soil emissions during rice production were accounted for, based on the yield-scaled GWP of partial and complete straw removal of 477 and $174 \mathrm{~kg} \mathrm{CO}_{2}$-eq $\mathrm{Mg}^{-1}$ straw, respectively [7]. The direct soil emissions measured the GWP of $\mathrm{CH}_{4}$ and $\mathrm{N}_{2} \mathrm{O}$ of different rice straw management practices; in this case, the scenarios' partial or complete straw removal are both applicable since rice straw was collected and used for RBHG. The calculated GHG emissions for rice production (without allocation), rice straw collection, and transportation using secondary data are found in Table 3.

To evaluate the energy depreciation of the structures (storage center and dRF), the embodied energy or energy expended by all the processes related with construction (including mining and processing of natural resources) [38] was calculated based on the BOQ and the energy equivalents in Tables 2 and 3. The structure of energy depreciation was calculated using Equation (3), and Equation (4) was used to calculate for the structure GHG emissions per Mg rice straw.

$$
\text { Structure energy depreciation }\left(\mathrm{MJ} \mathrm{Mg}^{-1}\right)=\text { Embodied energy } /(\mathrm{Qy} * \mathrm{LS})
$$

Structure GHG emissions $\left(\mathrm{kg} \mathrm{CO}_{2}\right.$-eq $\left.\mathrm{Mg}^{-1}\right)=$ Embodied GHG emissions $/(\mathrm{Qy} * \mathrm{LS})$ 
where the structure energy depreciation is in $\mathrm{MJ} \mathrm{Mg}^{-1}$ straw, the embodied energy is in MJ; Qy is the annual capacity of the structure in $\mathrm{Mg} \mathrm{yr}^{-1}$, and LS is the life span of the storage center or $\mathrm{dRF}$ in years. Table 5 includes the data on the annual capacity and lifespan of the storage center and dRF. Likewise, the GHG emissions per Mg rice straw of the structures were evaluated by getting the embodied GHG emissions using the BOQ and emission factors in Tables 2 and 3.

Table 5. Investment and specifications of cost items.

\begin{tabular}{|c|c|c|c|}
\hline Parameter & Baler & Storage Center & dRF \\
\hline Investment cost (USD) & 28,800 & 23,000 & 1515 \\
\hline Workshop for parking and maintenance (USD) & 2000 & & \\
\hline Life span (years) & 5 & 10 & 5 \\
\hline Working time (hours day ${ }^{-1}$ ) & 8 & 24 & 16 \\
\hline Maintenance and repair cost $(\%)$ & 50 & 20 & 50 \\
\hline Working days each year (days) & $60-90$ & 300 & 60 \\
\hline Capacity $\left(\mathrm{Mg} \mathrm{yr}^{-1}\right)$ & 960 & $80-320$ & $19-29$ \\
\hline Tractor rental price $\left(\mathrm{USD}^{-1}\right)$ & 4.8 & & \\
\hline Baler service management (USD man $^{-1}$ day $^{-1}$ ) & 4.8 [39] & & \\
\hline
\end{tabular}

Note: Exchange rate of 1 USD = 52.10 PHP [27].

$\mathrm{CH}_{4}$ and $\mathrm{N}_{2} \mathrm{O}$ emissions during the combustion of rice straw in the furnace were considered using the emission factors $0.70-9.6 \mathrm{~g} \mathrm{~kg}^{-1}$ dry straw for $\mathrm{CH}_{4}$ and $0.033-0.264 \mathrm{~g} \mathrm{~kg}^{-1}$ dry straw for $\mathrm{N}_{2} \mathrm{O}$ for dry straw, based on 10-15\% moisture content [7,40-42]. The GWP of the two gases were 30.5 and $265 \mathrm{~kg} \mathrm{CO}_{2}$-eq kg ${ }^{-1}$ for $\mathrm{CH}_{4}$ and $\mathrm{N}_{2} \mathrm{O}$, respectively [29].

In terms of outputs, the contributions of the rice paddy were excluded since economic allocation was done. Thus, only two products (heat and ash) were considered. The dRF heat output was based on the study of Migo-Sumagang et al. [17]. The avoidance of kerosene combustion was accounted for in the GHG avoided. The kerosene combustion emission factor used was $71 \mathrm{~kg} \mathrm{CO}_{2} \mathrm{GJ}^{-1}[36,37]$.

In rice straw combustion, the bottom product composed of ash and unburnt combustibles is considered as a byproduct with applications in concrete aggregate replacement. Concrete, which is a mixture of Portland cement, coarse and fine aggregates, and water, depends on aggregates for $65 \%$ of its composition [43]. Many studies have shown that substituting the fine aggregates in concrete (commonly sand) with coal or municipal solid waste incinerator bottom or fly ash have exhibited higher compressive strength, expansion control, and slowing down of water penetration [43-46]. These ashes are rich in silica, which is also found abundantly in rice straw ash $[47,48]$. For both energy and GHG emissions, the weight of the ash byproduct was accounted as a concrete aggregate replacement using the equivalent factors for sand manufacturing and transportation [29] in Table 4.

Energy analysis was done by calculating the net energy ( $\left.\mathrm{MJ} \mathrm{Mg}^{-1}\right)$, energy ratio, and percent net energy using Equations (5)-(7), based on the total energy input and output $[8,21,49]$. The net energy in GJ ha ${ }^{-1}$ in Equation (8) was calculated for comparison with other studies. The net GHG emissions $\left(\mathrm{kg} \mathrm{CO}_{2}\right.$-eq $\left.\mathrm{Mg}^{-1}\right)$ was calculated using Equation (9), and Equation (10) was used in converting the net GHG emissions in terms of $\mathrm{kWh}$, where SFR is in $\mathrm{kg} \mathrm{h}^{-1}$, dRF heat output is in $\mathrm{MJ} \mathrm{h}^{-1}$, and 1000 and 3.6 are conversion factors.

$$
\begin{gathered}
\text { Net energy }\left(\mathrm{MJ} \mathrm{Mg}^{-1}\right)=\text { Energy output }\left(\mathrm{MJ} \mathrm{Mg}^{-1}\right)-\text { Energy input }\left(\mathrm{MJ} \mathrm{Mg}^{-1}\right) \\
\text { Energy ratio }=\text { Energy output }\left(\mathrm{MJ} \mathrm{Mg}^{-1}\right) / \text { Energy input }\left(\mathrm{MJ} \mathrm{Mg}^{-1}\right) \\
\% \text { Net energy }=\text { Net energy }\left(\mathrm{MJ} \mathrm{Mg}^{-1} / \text { Energy input }\left(\mathrm{MJ} \mathrm{Mg}^{-1}\right) * 100\right.
\end{gathered}
$$

Net energy $\left(\mathrm{GJ} \mathrm{ha}^{-1}\right)=$ Net energy $\left(\mathrm{MJ} \mathrm{Mg}^{-1}\right) * \mathrm{Y}_{\mathrm{rs}} / 1000$ 


$$
\begin{gathered}
\text { Net GHG emissions }\left(\mathrm{kg} \mathrm{CO}_{2} \text {-eq } \mathrm{Mg}^{-1}\right) \\
=\text { GHG emissions }\left(\mathrm{kg} \mathrm{CO}_{2} \text {-eq } \mathrm{Mg}^{-1}\right)-\mathrm{GHG} \text { avoided }\left(\mathrm{kg} \mathrm{CO}_{2} \text {-eq Mg}{ }^{-1}\right)
\end{gathered}
$$

Net GHG emissions $\left(\mathrm{kg} \mathrm{CO}_{2}\right.$-eq $\left.\mathrm{kWh}^{-1}\right)=\left[\mathrm{Net} \mathrm{GHG}\right.$ emissions $\left(\mathrm{kg} \mathrm{CO}_{2}\right.$-eq $\left.\mathrm{Mg}^{-1}\right)$ * $\mathrm{SFR} * 3.6] /[\mathrm{dRF}$ heat output $* 1000]$

\subsection{RBHG Cost Calculations}

RBHG cost depended on inputs such as fuel, labor, and materials used during heat generation. Depreciation, maintenance, and interest of the storage center and dRF (blower, motor, and furnace) were also included. Only one type of baler (CLAAS Markant 55, $45 \mathrm{HP}$ ) was evaluated in the cost calculations using Equation (11).

$$
\begin{gathered}
\text { RBHG Cost }\left(\mathrm{USD} \mathrm{kWh}^{-1}\right)=[\mathrm{ML} * \mathrm{LC}+\mathrm{BPC} * \mathrm{EC}+\mathrm{SFR} * \mathrm{RSC}+(\mathrm{TC}+\mathrm{DC}+\mathrm{SC}) * \\
\mathrm{SFR} / 1000] * 3.6 / \mathrm{dRF} \text { heat output }
\end{gathered}
$$

where RBHG cost is in USD $\mathrm{kWh}^{-1} \mathrm{dRF}$ heat output, ML is the number of manual labor, LC is the cost of manual labor which is $0.84 \mathrm{USD} \mathrm{man}^{-1} \mathrm{~h}^{-1}$ [39], BPC is the blower electricity consumption in $\mathrm{kW}, \mathrm{EC}$ is the price of electricity which is $0.20 \mathrm{USD} \mathrm{kWh}^{-1}$ [50], SFR is the rice straw feed rate in $\mathrm{kg} \mathrm{h}^{-1}, \mathrm{RSC}$ is the price of rice straw USD kg${ }^{-1}, \mathrm{TC}$ is the transportation cost in USD Mg${ }^{-1}, \mathrm{DC}$ is the furnace depreciation and maintenance cost in USD $\mathrm{g}^{-1}, \mathrm{SC}$ is the rice straw storage depreciation and maintenance cost in USD $\mathrm{Mg}^{-1}$, dRF heat output is in $\mathrm{MJ} \mathrm{h}^{-1}$, and 3.6 is a conversion factor.

The price of baled straw was based on financial analysis, taking into account investment, depreciation, interest, labor, fuel, tractor rental, tax, and transportation costs. The investment cost of a CLAAS Markant 55 baler was obtained from a baler sales company, Agri Component Corporation. All the other specifications of the baler were obtained from the manufacturer's manual. A $10 \%$ equipment transportation cost, as well as a 10\% tax, were included in the total cost. Equations (12) and (13) show the calculations for depreciation and interest, respectively.

$$
\begin{aligned}
& \mathrm{D}=\mathrm{IV} /(\mathrm{LS} * \mathrm{Qy}) \\
& \mathrm{Ir}_{\mathrm{s}}=\mathrm{IV} * \mathrm{Ir}_{\mathrm{b}} / \mathrm{Qy}
\end{aligned}
$$

where $\mathrm{D}$ is the depreciation of the item in USD $\mathrm{Mg}^{-1}$, IV is the investment cost in USD, LS is the lifespan of the item in years, Qy is the annual capacity in $\mathrm{Mg}_{\text {year }}{ }^{-1}, \mathrm{Ir}_{\mathrm{s}}$ is the interest of the service, and $\operatorname{Ir}_{\mathrm{b}}$ is the bank interest (12\%). Maintenance and repair costs were based on percentage factors in Table 5 multiplied to the depreciation cost. Equation (12) was also used in the dRF and storage center depreciation cost calculations, considering maintenance and repair factors. The investment cost and specifications of the storage center and dRF were obtained from a civil engineer and furnace fabricator, respectively.

Transportation cost was based on a diesel price of 0.82 USD L $^{-1}$ [51], fuel consumption of $2.18 \mathrm{~L}$ $\mathrm{Mg}^{-1}$ for a distance of $4 \mathrm{~km} \mathrm{[8],} \mathrm{driving} \mathrm{tractor} \mathrm{and} \mathrm{trailer} \mathrm{capacity} \mathrm{of} 13.13 \mathrm{Mg} \mathrm{h}^{-1}$ [8], and driving manual labor cost of $0.96 \mathrm{USD} \mathrm{man}^{-1} \mathrm{~h}^{-1}$ [39]. The calculated transportation cost was $1.86 \mathrm{USD} \mathrm{Mg}^{-1}$ for a distance of $4 \mathrm{~km}$.

The annual capacity of the storage center (assuming two harvest seasons) was based on the baled straw density from literature values, ranging from 81.47 to $331 \mathrm{~kg} \mathrm{~m}^{-3}$, with an average of $157.16 \mathrm{~kg} \mathrm{~m}^{-3}$ at $8-14 \%$ moisture content dry basis $[17,48,52]$. On the other hand, the annual capacity of the dRF was based on the optimized straw feed rates of 20.67 to $28.06 \mathrm{~kg} \mathrm{~h}^{-1}$ SFR [17]. 


\section{Results}

\subsection{Results of the RBHG Experiments}

Table 6 presents the results of the RBHG experiments. In the heat generation experiments, the blower electricity consumption for Scenario 1 conditions was between 16.30 and $19.92 \mathrm{~kW}$, with a mean $18.38(1.87) \mathrm{kW}$, while that of Scenario 2 was between 11.17 and $11.81 \mathrm{~kW}$ with a mean of $11.48(0.32) \mathrm{kW}$. The blower electricity consumption of Scenario 1 was higher compared to Scenario 2 due to the higher airflow rate setting of Scenario 1.

Table 6. Results of the RBHG experiments and labor energy measurements.

\begin{tabular}{ccccc}
\hline Scenario & $\begin{array}{c}\text { Blower Electricity Consumption } \\
\mathbf{( k W )}\end{array}$ & $\begin{array}{c}\text { ASH } \\
\mathbf{( k g ~ h} \mathbf{- 1})\end{array}$ & Stage & $\begin{array}{c}\text { Labor Energy } \\
\left(\mathbf{M J ~ M g}^{\mathbf{- 1}} \mathbf{)}\right.\end{array}$ \\
\hline Scenario 1 & & & Storage & \\
Range & $16.30-19.92$ & $6-6.11$ & & $4.68-6.24$ \\
Average & 18.38 & 6.03 & & 5.42 \\
STDEV & 1.87 & 0.07 & & 0.78 \\
\hline Scenario 2 & & & dRF Operation & \\
Range & $11.17-11.81$ & $4-4.28$ & & $5.52-6.87$ \\
Average & 11.48 & 4.17 & & 6.03 \\
STDEV & 0.32 & 0.17 & & 0.73 \\
\hline
\end{tabular}

The ash output for Scenario 1 was between 6 and $6.11 \mathrm{~kg} \mathrm{~h}^{-1}$, with a mean of $6.03(0.07) \mathrm{kg} \mathrm{h}^{-1}$, while that of Scenario 2 was between 4 and $4.28 \mathrm{~kg} \mathrm{~h}^{-1}$, with a mean of $4.17(0.17) \mathrm{kg} \mathrm{h}^{-1}$. The ash production in Scenario 1 was higher compared to Scenario 2 due to the higher straw feed rate in Scenario 1. Naturally, Scenario 1 had higher heat output as compared to Scenario 2 [10] due to the higher straw feed rate.

The labor energy per $\mathrm{Mg}$ straw was between 4.68 and $6.24 \mathrm{MJ} \mathrm{Mg}^{-1}$ with a mean of $5.42(0.78)$ $\mathrm{MJ} \mathrm{Mg}{ }^{-1}$ for storage and between 5.52 and $6.87 \mathrm{MJ} \mathrm{Mg}^{-1}$ with mean of $6.03(0.73) \mathrm{MJ} \mathrm{Mg}^{-1}$ for dRF operation.

\subsection{Energy Flow and GHG Emissions}

The energy input per megagram straw during paddy production ranged from 2725 to 9053 $\mathrm{MJ} \mathrm{Mg}^{-1}$. Due to the much higher economic value of rice paddy as compared to straw, rice straw allocation only ranged from 3.74 to $4.92 \%$, and the rest was allocated to the rice paddy. Table 7 shows the summarized energy flow and GHG emissions for RBHG. The allocation for rice straw in rice production based on secondary data was only between 118 and $392 \mathrm{MJ} \mathrm{Mg}^{-1}$ for energy and between 9 and $33 \mathrm{~kg} \mathrm{CO}_{2}$-eq $\mathrm{Mg}^{-1}$ for GHG emissions. Data on rice straw collection and transportation based on secondary data were converted to their equivalent input energy and GHG emissions, also reported in Table 7. The converted input energy and GHG emissions for the first two stages, rice straw production and rice straw collection and transportation, had comparable values.

The construction of the 200 sq. meter and 3-meter-high storage center expended a total of embodied energy of $254 \mathrm{GJ}$, equivalent to $1270 \mathrm{MJ}$ per sq. meter. In terms of energy depreciation, the calculated energy depreciation per $\mathrm{Mg}$ of rice straw using Equation (3) ranged from 79 to $318 \mathrm{MJ}$ $\mathrm{Mg}^{-1}$ for the storage center (Table 7). The embodied GHG emissions for the construction of the storage center was $32,810 \mathrm{~kg} \mathrm{CO}_{2}$-eq, or $164 \mathrm{~kg} \mathrm{CO}_{2}$-eq per sq. meter. Thus, the GHG emissions per $\mathrm{Mg}$ rice straw ranged from 10 to $41 \mathrm{~kg} \mathrm{CO}_{2}$-eq $\mathrm{Mg}^{-1}$ for the storage center. 
Table 7. Energy flow and GHG emissions balance for RBHG.

\begin{tabular}{|c|c|c|}
\hline Parameter & Energy & GHG \\
\hline & $\mathrm{MJ} \mathrm{Mg}^{-1}$ & $\mathrm{~kg} \mathrm{CO}_{2}$-eq $\mathrm{Mg}^{-1}$ \\
\hline & INPUT & EMISSIONS \\
\hline Rice straw production (rice production with allocation) $*, 1$ & 118-392 & $9-33$ \\
\hline Rice straw collection and transportation * & $131-253$ & $12-23$ \\
\hline & \multicolumn{2}{|c|}{ Rice straw storage } \\
\hline Labor & $4.7-6.2$ & \\
\hline Storage center energy depreciation/GHG emissions & $79-318$ & $10-41$ \\
\hline Subtotal rice straw storage & $84-324$ & $10-41$ \\
\hline \multicolumn{3}{|l|}{ Rice-straw-based heat generation } \\
\hline Labor & $5.7-6.9$ & \\
\hline Blower electricity consumption & $6218-7334$ & $496-794$ \\
\hline dRF energy depreciation/GHG emissions & $152-232$ & $14.5-22$ \\
\hline Rice straw combustion emissions $\left(\mathrm{CH}_{4}\right.$ and $\left.\mathrm{N}_{2} \mathrm{O}\right)$ & & $26-316$ \\
\hline Subtotal RBHG & $6376-7573$ & 537-1132 \\
\hline \multirow[t]{2}{*}{ Total Energy Input/GHG Emissions } & $6709-8542$ & $742-1706$ \\
\hline & OUTPUT & AVOIDED \\
\hline dRF heat output & $11,198-11,849$ & \\
\hline Kerosene combustion avoided & & $801-847$ \\
\hline Ash as concrete aggregate & $38-41$ & $2.4-2.6$ \\
\hline Total Energy Output/GHG Avoided & $11,236-11,890$ & $803-850$ \\
\hline Net Total Energy Output/GHG Emissions & $3348-4527$ & $(-) 61-856$ \\
\hline Energy Ratio & $1.4-1.7$ & \\
\hline$\%$ Net Energy & $39-67$ & \\
\hline
\end{tabular}

${ }^{*}$ based on secondary data in Table $3 ;{ }^{1}$ multiplied by the percent allocation for rice straw, 3.74 to $4.92 \%$.

During the heat generation stage, the construction of the furnace (dRF) expended a total embodied energy of $22.1 \mathrm{GJ}$, corresponding to an energy depreciation between 152 and $232 \mathrm{MJ} \mathrm{Mg}^{-1}$ rice straw using Equation (4). The embodied GHG emissions in the construction of the furnace were $2100 \mathrm{~kg} \mathrm{CO}_{2}$-eq. Thus, the GHG emissions per Mg rice straw ranged between 14.5 and $22 \mathrm{~kg} \mathrm{CO}_{2}$-eq $\mathrm{Mg}^{-1}$ for the dRF. The converted blower electricity consumption ranged from 6218 to $7334 \mathrm{MJ} \mathrm{Mg}^{-1}$, while the GHG emissions ranged from 496 to $794 \mathrm{~kg} \mathrm{CO}_{2}$-eq $\mathrm{Mg}^{-1}$ rice straw, using the emission factors in Table 4 . The rest of the contributions during the heat generation stage and the outputs are also reported in Table 7.

The net total positive energy ranged between 3348 and $4527 \mathrm{MJ} \mathrm{Mg}^{-1}$ rice straw, while the net total GHG emissions ranged between (-)61 and $856 \mathrm{~kg} \mathrm{CO}_{2}$-eq $\mathrm{Mg}^{-1}$ rice straw, wherein the negative sign of the lower range indicates GHG avoidance instead of emission. The total net energy corresponded to an energy ratio between 1.4 and 1.7 and percent net energy between 39 and $67 \%$.

Figure 2 summarizes the percentages of the energy flow and GHG emissions. During the heat generation stage, the blower electricity consumption required the highest input energy at an average of $97 \%$ of the total input energy (Figure 2a). The furnace energy depreciation was only at an average of 3\% of the total input energy in this stage, and the manual labor energy is almost negligible at an average of $0.09 \%$. Blower electricity consumption also emitted the highest GHG at an average of $77 \%$ of the total emissions during the heat generation stage (Figure 2a). Rice straw combustion emissions from the release of $\mathrm{CH}_{4}$ and $\mathrm{N}_{2} \mathrm{O}$ accounted for an average of $21 \%$ (Figure $2 \mathrm{a}$ ), followed by furnace construction emissions at $2 \%$ in the heat generation stage. 

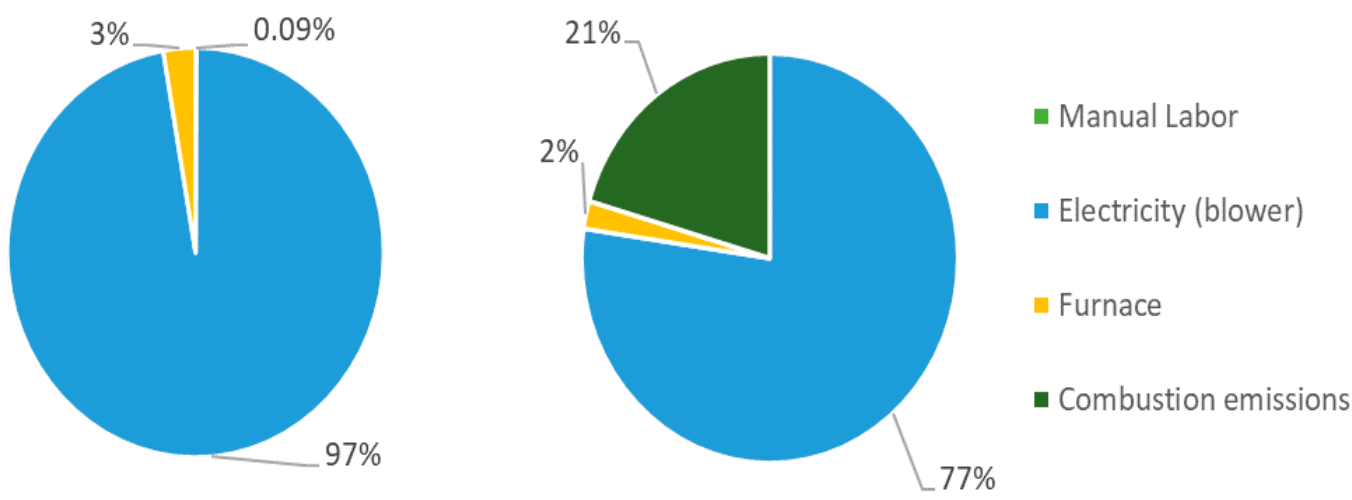

Input Energy

GHG

(a) Heat Generation Stage

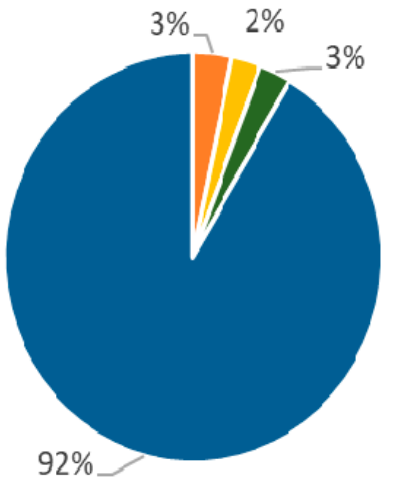

Input Energy

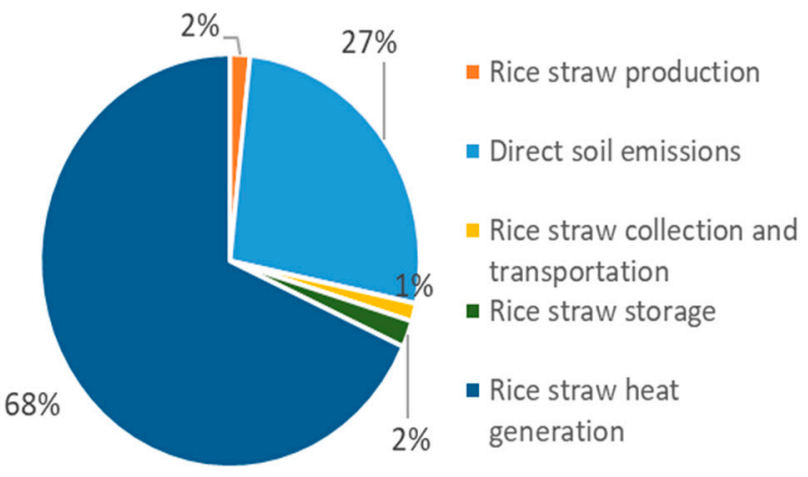

GHG

(b) Rice-Straw-Based Heat Generation (All Stages)

Figure 2. Percentages of input energy and Greenhouse gas (GHG) emissions in the (a) heat generation stage, (b) rice-straw-based heat generation (all stages).

In terms of the total input energy and GHG emissions for all the stages, the highest input energy was during the heat generation stage, at an average of $92 \%$ of the total input energy, and an average of $68 \%$ of the total GHG emissions for all stages (Figure 2b). The rest of the stages ranged from 2 to $3 \%$ of the total input energy. Direct soil emissions followed as the next highest contributor of GHG emissions in all stages at an average of $27 \%$, while the rest of the stages ranged from 1 to $2 \%$ of the total GHG emissions (Figure 2b).

In the outputs, the heat product dominated the total input energy, while the ash byproduct had minimal contribution (Table 7). Nevertheless, it was important to consider the use of the ash byproduct as a means of waste disposal. GHG emissions from the avoidance of kerosene combustion (801 to $847 \mathrm{~kg} \mathrm{CO}_{2}$-eq $\mathrm{Mg}^{-1}$ ) is higher compared to combustion emissions from rice straw (26 to $316 \mathrm{~kg} \mathrm{CO}_{2}$-eq $\mathrm{Mg}^{-1}$ ).

\subsection{Cost Calculations}

In the cost calculations, rice straw production and baling were grouped as the cost of baled straw. The estimated cost of baled straw in the Philippines ranged from 17.8 to $22.2 \mathrm{USD} \mathrm{Mg}^{-1}$ straw. However, for a profitable straw baler service provider with a time of capital return from 1.4 to 2.8 years, baled 
straw price is around $33 \mathrm{USD} \mathrm{Mg}^{-1}$ straw. Transportation cost for a $4 \mathrm{~km}$ distance was $1.86 \mathrm{USD} \mathrm{Mg}^{-1}$ straw. In terms of the dRF heat output, the cost of a storage center, labor for dRF operation, electricity, and dRF are presented in Table 8. The total cost ranged from 0.0796 to $0.1127 \mathrm{USD}_{\mathrm{kWh}}{ }^{-1}$.

Table 8. Cost of rice-straw-based heat generation (RBHG) in the Philippines.

\begin{tabular}{|c|c|c|c|}
\hline \multirow[t]{2}{*}{ Inputs } & \multicolumn{2}{|c|}{ Cost } & \multirow{2}{*}{$\begin{array}{c}\begin{array}{c}\text { Percentage of } \\
\text { Average Value }\end{array} \\
\%\end{array}$} \\
\hline & $\begin{array}{l}\text { USD } \mathrm{Mg}^{-1} \\
\text { Rice Straw }\end{array}$ & $\begin{array}{l}\text { USD kWh }^{-1} \\
\text { Heat Output }\end{array}$ & \\
\hline Rice straw & 33 & 0.0106 & 11.04 \\
\hline Transportation & 1.86 & 0.0006 & 0.62 \\
\hline Storage center maintenance and depreciation & $18.2-69$ & $0.0059-0.0222$ & 14.58 \\
\hline Labor for dRF operation & $59.9-81.2$ & $0.0193-0.0261$ & 23.59 \\
\hline Blower electricity consumption & $111-131$ & $0.0357-0.0421$ & 40.47 \\
\hline $\mathrm{dRF}$ maintenance and depreciation & $23.6-34.4$ & $0.0076-0.0111$ & 9.70 \\
\hline Total cost & $248-350$ & $0.0796-0.1127$ & 100 \\
\hline
\end{tabular}

\section{Discussion}

The lower range of the input energy during paddy production of this study is comparable with similar studies, which had values between 1730 and $2520 \mathrm{MJ} \mathrm{Mg}^{-1}[9,19]$. The lower range of the straw collection and transportation is also comparable with that of rice straw collection from similar studies, which ranged between 38 and $110 \mathrm{MJ} \mathrm{Mg}^{-1}$ [9,19]. As for the higher range of the input energy, the difference may be due to the manual labor considered in the study. The GHG emissions during collection and transportation are lower compared to similar studies (132 to $\left.394 \mathrm{~kg} \mathrm{CO}_{2}-\mathrm{eq} \mathrm{Mg}^{-1}\right)[6,13,19]$, possibly due to the shorter distance considered in this study.

Heating value and moisture content affect the performance and efficiency of combustion $[5,17,53]$. There is a loss in heating value due to the adsorption of water vapor, oxidation, and biochemical reactions during storage $[48,54]$. Thus, it was necessary to include storage in the life cycle analysis of RBHG. A roofed facility with minimal features was chosen in this study. Comparisons were made with more complex residential structures in terms of input energy and GHG emissions per sq. meter to verify the simplicity of the presumed structure. Results show that the assessed input energy and GHG emissions of the presumed storage center are expectedly lower compared to more complex residential houses with input energies between 3000 and $9740 \mathrm{MJ}$ per sq. meter [55,56] and GHG emissions of 165 to $665 \mathrm{~kg} \mathrm{CO}$-eq per sq. meter [57,58]. The resulting input energy of the storage center was wide-ranged due to the wide range of annual storage capacity considered, which depended on factors such as rice straw density and availability.

The measured labor energy for storage and dRF operation is comparable to the labor energy reported from another study, which is $4.78 \mathrm{MJ} \mathrm{Mg}^{-1}$ for manual straw handling (collecting rice straw to the bund, loading, and unloading) and $6.41 \mathrm{MJ} \mathrm{Mg}^{-1}$ for manual piling of rice straw $[8,23]$. The closeness with literature values may be explained by the fact that the dRF operation included similar activities such as weighing and feeding of straw into the hopper for combustion.

The blower electricity consumption required the highest input energy during the heat generation stage and also emitted the highest GHG. The significant input energy and GHG emissions from electricity consumption included the contributions from power generation and transmission [29], with factors of $3.11 \mathrm{MJ} \mathrm{MJ}^{-1}$ and $0.21 \mathrm{~kg} \mathrm{CO}_{2}$-eq MJ ${ }^{-1}$ for input and GHG emissions, respectively (Table 4). Thus, other types of motors, such as diesel-powered, may be explored to decrease the input energy and GHG emissions.

In terms of the total input energy and GHG emissions for all the stages, the highest input energy and GHG emissions were during the heat generation stage. The results can be attributed to the blower electricity consumption during heat generation, which required the highest input energy and emitted the highest GHG. The percent net energy output of RBHG is lower compared to that of a small-scale anaerobic digestion study, which is around 71 to $85 \%$ [8]. The difference may be attributed to the high 
input energy during the heat generation stage, specifically the high blower electricity input energy. The energy ratio or energy use efficiency is also comparable to the results of input-output energy analyses from literature (1.39 to 1.72) in Iran [20,49,59], but lower than the values from a study in China (6.81 to 9.94) [21]. It is important to note that the mentioned input-output studies directly considered the energy values of paddy and straw in the output energy and excluded the energies in rice straw processing. RBHG net energy converts to $10.59 \mathrm{GJ} \mathrm{ha}^{-1}$ using Equation (8). Comparing the energy flow of RBHG with that of rice straw soil incorporation and open-field burning, RBHG adds more value to the energy flow since the outputs of soil incorporation $\left(1.35 \mathrm{GJ} \mathrm{ha}^{-1}\right)$ and open-field burning $\left(0.34 \mathrm{GJ} \mathrm{ha}^{-1}\right)$ only include rice straw as fertilizer, with corresponding nutrient losses [14].

Furnace combustion emissions are comparable or lower than open-field burning, which ranged

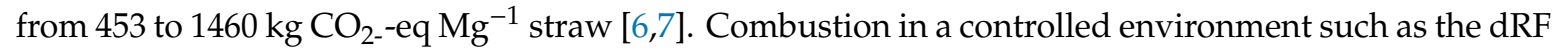
can improve the efficiency and completion of the process [17] over the uncontrolled open-field burning. To compare RBHG with soil incorporation and open-field burning scenarios, it was essential to consider the direct soil emissions in complete or partial removal of rice straw, as shown in Table 7. Direct soil emissions in the complete straw removal scenario come from the incorporation of the remaining rice straw stubbles that favor $\mathrm{CH}_{4}$ formation, as well as $\mathrm{N}_{2} \mathrm{O}$ emissions during fertilizer application [7]. The net GHG emissions imply that the best case of RBHG would result in net GHG avoidance, indicated by the negative value ( $-61 \mathrm{~kg} \mathrm{CO}_{2}$-eq $\left.\mathrm{Mg}^{-1}\right)$. The best case of RBHG is better compared to the yield-scaled GWP of soil incorporation with emissions of 881 and $1025 \mathrm{~kg} \mathrm{CO}_{2}$-eq Mg and open-field burning with emissions of 453 and $1460 \mathrm{~kg} \mathrm{CO}_{2}$-eq $\mathrm{Mg}^{-1}$ [6,7]. On the other hand, the worst case of RBHG is just comparable with that of soil incorporation.

The average net GHG emissions in this study convert to $0.12 \mathrm{~kg} \mathrm{CO}_{2}$-eq $\mathrm{kWh}^{-1}$ using Equation (10), lower compared to the literature value of rice-straw-based electricity generation $\left(0.845 \mathrm{~kg} \mathrm{CO}_{2}\right.$-eq $\left.\mathrm{kWh}^{-1}\right)$ in Malaysia [19], higher than that in Thailand $\left(0.043 \mathrm{~kg} \mathrm{CO}_{2}\right.$-eq $\left.\mathrm{kWh}^{-1}\right)$ [60], and comparable with that in India $\left(0.15 \mathrm{~kg} \mathrm{CO}_{2}\right.$-eq $\left.\mathrm{kWh}^{-1}\right)$ [13]. Studies on rice-straw-based electricity generation show that transportation may contribute a significant portion of the total GHG emissions $[9,13,19]$. As an example, transportation GHG emissions were up to $42 \%$ in a study where the distance of the rice straw collection area to the power plant was $250 \mathrm{~km}$ [19]. In another study, transportation contributed up to $81.68 \%$ for a rice-straw-based electric power plant [9]. On the other hand, the distance considered in this study was only $4 \mathrm{~km}$. As a result, collection and transportation only contributed $1 \%$ of the GHG emissions during the rice preparation stage. For a small-scale RBHG system, a long distance from the rice straw collection area to the dRF unit is not required since individual dRF units may be installed near the rice fields. Thus, small-scale systems may improve the overall GHG emissions with respect to transportation.

The estimated cost of baled straw in the Philippines ranged from 17.8 to $22.2 \mathrm{USD} \mathrm{Mg}^{-1}$ straw, but it was set to $33 \mathrm{USD} \mathrm{Mg}^{-1}$ for a profitable straw baler service provider. This value was lower compared to $38 \mathrm{USD} \mathrm{Mg}^{-1}$, which was the information gathered from farmers in Nueva Ecija, Philippines [8]. Rice straw cost only accounted for $11.04 \%$ of the total cost of RBHG (Table 8). Blower electricity consumption accounted for the highest cost $(40.47 \%)$, followed by labor $(23.59 \%)$ and storage $(14.58 \%)$. Alternatives to an electric motor and storage may be explored to drive down the cost. Transportation contributed only $0.62 \%$ to the cost, due to the short distance between the rice straw collection and the storage center and furnace. Thus, the energy conversion area must be located strategically to drive down transportation costs [5]. The average total cost of RBHG is $0.096 \mathrm{USD} \mathrm{kWh}^{-1}$, lower compared to the paddy drying cost of 0.13 to $0.15 \mathrm{USD} \mathrm{kWh}^{-1}$ in the Philippines [61,62]. The cost is also lower compared to a $500 \mathrm{~kW}$ steam power plant $\left(0.21 \mathrm{USD} \mathrm{kWh}^{-1}\right)$ in Japan within a $3 \mathrm{~km}$ distance [63], but slightly higher compared to the cost of a $5 \mathrm{MW}$ rice-straw-based electricity generation system in Thailand within $70 \mathrm{~km}$ from the collection point $\left(0.0889 \mathrm{USD} \mathrm{kWh}^{-1}\right)$ [60]. The cost is comparable with the selling price of pelletized rice straw in Japan from literature $\left(0.29 \mathrm{USD} \mathrm{kg}^{-1}\right.$ straw) within a $20 \mathrm{~km}$ radius from the collection point [64]. 


\section{Conclusions}

The highest contributor among all the stages (rice straw production, straw collection and transportation, storage, and heat generation) in the total input energy and GHG emissions was from the heat generation stage due to the blower electricity consumption. Because of the short distance assumed in this study $(4 \mathrm{~km})$, collection and transportation only contributed $1 \%$ of the total GHG emissions in the rice straw preparation stage. The RBHG energy ratio was between 1.4 and 1.7, and the percent net energy was between 39 and 67\%; RBHG improves the net energy flow over soil incorporation and open-field burning since the last two options only consider rice straw as fertilizer with nutrient losses. The best case of RBHG offers a possibility of a net GHG avoided $\left(-61 \mathrm{~kg} \mathrm{CO}_{2}\right.$-eq $\left.\mathrm{Mg}^{-1}\right)$ in contrast with soil incorporation and open-field burning, while the worst case has a net GHG emission comparable with soil incorporation. Blower electricity consumption accounted for the highest cost, followed by labor cost. Thus, alternatives to an electric motor and storage may be explored to drive down not only the input energy and GHG emissions but also the cost of RBHG. In contrast, transportation contributed the lowest cost, due to the short distance considered $(4 \mathrm{~km})$. The average total cost of RBHG (0.096 USD kWh ${ }^{-1}$ ) was lower compared to the paddy drying cost in the Philippines.

The results of this study show that RBHG adds more value to the energy flow compared to soil incorporation and open-field burning. A small-scale RBHG system may also be advantageous over rice-straw-based electricity generation since long distances from the rice straw collection point may not be required, as individual furnace units may be installed near rice fields. Overall, RBHG is a technology with the potential to improve the energy flow, GHG emissions, and the cost of rice production systems.

Author Contributions: Conceptualization, M.C.M.-D., N.V.H., M.G., C.G.A., M.G.B., J.A.C.; methodology, M.V.P.M.-S., N.V.H., M.C.M.-D., M.G., C.G.A., M.G.B., J.A.C.; software: N.V.H.; validation, N.V.H. and M.V.P.M.-S.; writing—original draft, M.V.P.M.-S. and M.C.M.-D.; writing—review and editing, N.V.H., M.C.M.-D., M.G., C.G.A., M.G.B., J.A.C.; supervision: N.V.H. and M.C.M.-D. All authors have read and agreed to the published version of the manuscript.

Funding: This research was funded by (1) The Philippine Department of Agriculture through the project "Sustainable rice straw management for bioenergy, food, and feed in the Philippines)", Grant Ref. 101101-03-042-2018; (2) The German Federal Ministry for Economic Cooperation and Development through the "Scalable straw management options for improved livelihoods, sustainability, and low environmental footprint in rice-based production systems," Grant Ref. 15.7860.8-001.00; and (3) Flagship Program 2, Upgrading Rice Value Chains of the CGIAR Research Program on Rice (RICE).

Acknowledgments: The authors acknowledge the valuable support of the management and research support teams in the International Rice Research Institute and the support of Eduardo Secretario, Engr. Ampy Paulo Roxas, Engr. Joseph Sandro, and Engr. Carlito Balingbing for their assistance and expert advice.

Conflicts of Interest: The authors declare no conflict of interest.

\section{References}

1. Food and Agriculture Organization of the United Nations (FAO). Rice Market Monitor. 2017. Available online: http://www.fao.org/economic/est/publications/rice-publications/rice-market-monitor-rmm/en/ (accessed on 19 December 2018).

2. Mendoza, T.C.; Samson, R.O.G.E.R. Strategies to Avoid Crop Residue Burning in the Philippine Context. 1999. Available online: https://www.reap-canada.com/online_library/IntDev/id_eco_sugarcane/9 (accessed on 12 December 2018).

3. Van Hung, N.; Quilloy, R.; Gummert, M. Improving energy efficiency and developing an air-cooled grate for the downdraft rice husk furnace. Renew. Energy 2018, 115, 969-977. [CrossRef]

4. Kadam, K.L.; Forrest, L.H.; Jacobson, W.A. Rice straw as a lignocellulosic resource: Collection, processing, transportation, and environmental aspects. Biomass Bioenergy 2000, 18, 369-389. [CrossRef]

5. Logeswaran, J.; Shamsuddin, A.H.; Silitonga, A.S.; Mahlia, T.M.I. Prospect of using rice straw for power generation: A review. Environ. Sci. Pollut. Res. 2020. [CrossRef] [PubMed]

6. Singh, A.; Basak, P. Economic and environmental evaluation of rice straw processing technologies for energy generation: A case study of Punjab, India. J. Clean. Prod. 2019, 212, 343-352. [CrossRef] 
7. Romasanta, R.R.; Sander, B.O.; Gaihre, Y.K.; Alberto, M.C.; Gummert, M.; Quilty, J.; Nguyen, V.H.; Castalone, A.G.; Balingbing, C.; Sandro, J.; et al. How does burning of rice straw affect CH4 and N2O emissions? A comparative experiment of different on-field straw management practices. Agric. Ecosyst. Environ. 2017, 239, 143-153. [CrossRef]

8. Nguyen, V.H.; Topno, S.; Balingbing, C.; Nguyen, V.C.N.; Röder, M.; Quilty, J.; Jamieson, C.; Thornley, P.; Gummert, M. Generating a positive energy balance from using rice straw for anaerobic digestion. Energy Rep. 2016, 2, 117-122. [CrossRef]

9. Said, N.; Alblawi, A.; Hendy, I.; Daiem, M.A. Analysis of Energy and Greenhouse Gas Emissions of Rice Straw to Energy Chain in Egypt. Bioresources 2020, 15, 1510-1520. [CrossRef]

10. He, L.; Huang, H.; Zhang, Z.; Lei, Z.; Lin, B. Le Energy Recovery from Rice Straw through Hydrothermal Pretreatment and Subsequent Biomethane Production. Energy Fuels 2017, 31, 10850-10857. [CrossRef]

11. Silalertruksa, T.; Gheewala, S.H. A comparative LCA of rice straw utilization for fuels and fertilizer in Thailand. Bioresour. Technol. 2013, 150, 412-419. [CrossRef]

12. Gadde, B.; Bonnet, S.; Menke, C.; Garivait, S. Air pollutant emissions from rice straw open field burning in India, Thailand and the Philippines. Environ. Pollut. 2009, 157, 1554-1558. [CrossRef]

13. Soam, S.; Borjesson, P.; Sharma, P.K.; Gupta, R.P.; Tuli, D.K.; Kumar, R. Life cycle assessment of rice straw utilization practices in India. Bioresour. Technol. 2017, 228, 89-98. [CrossRef] [PubMed]

14. Dobermann, A.; Fairhurst, T.H. Rice straw management. Better Crop. Int. 2002, 16, 7-11.

15. Knoblauch, R.; Ernani, P.R.; Deschamps, F.C.; Gatiboni, L.C.; Walker, T.W.; Lourenço, K.S.; Martins, A.A.; Pegoraro, A. Rice straw incorporated just before soil flooding increases acetic acid formation and decreases available nitrogen. Rev. Bras. Ciência Solo 2014, 38, 177-184. [CrossRef]

16. Philrice. Maligaya Flatbed Dryer. Pinoy Rice Knowledge Bank Handout Series. 2010. Available online: http://www.pinoyrice.com/wp-content/uploads/maligaya-flatbed-dryer.pdf (accessed on 3 September 2018).

17. Migo-Sumagang, M.V.P.; Van Hung, N.; Detras, M.C.M.; Alfafara, C.G.; Borines, M.G.; Capunitan, J.A.; Gummert, M. Optimization of a downdraft furnace for rice straw-based heat generation. Renew. Energy 2020, 148, 953-963. [CrossRef]

18. Singh, A. Life Cycle Assessment of Renewable Energy Sources; Springer: London, UK, 2016. [CrossRef]

19. Shafie, S.M.; Masjuki, H.H.; Mahlia, T.M.I. Life cycle assessment of rice straw-based power generation in Malaysia. Energy 2014, 70, 401-410. [CrossRef]

20. Kazemi, H.; Kamkar, B.; Lakzaei, S.; Badsar, M.; Shahbyki, M. Energy flow analysis for rice production in different geographical regions of Iran. Energy 2015, 84, 390-396. [CrossRef]

21. Yuan, S.; Peng, S. Input-output energy analysis of rice production in different crop management practices in central China. Energy 2017, 141, 1124-1132. [CrossRef]

22. Bautista, E.G.; Minowa, T. Analysis of the energy for different rice production systems in the Philippines. Philipp. Agric. Sci. 2010, 93, 346-357.

23. Quilty, J.R.; McKinley, J.; Pede, V.O.; Buresh, R.J.; Correa, T.Q.; Sandro, J.M. Energy efficiency of rice production in farmers' fields and intensively cropped research fields in the Philippines. Field Crop. Res. 2014, 168, 8-18. [CrossRef]

24. Blonk Consultants. Agri-Footprint 2.0 Part 1: Methodology and Basic Principles. 2015. Available online: https://simapro.com/wp-content/uploads/2018/02/Agri-Footprint-4.0-Part-1-Methodology-and-basicprinciples.pdf (accessed on 12 December 2018).

25. PRé Consultants. SimaPro Tutorial. 2016. Available online: https://www.pre-sustainability.com/download/ SimaPro8Tutorial.pdf (accessed on 12 December 2018).

26. Philippine Statistics Authority (PSA). Updates on Palay, Rice and Corn Prices. 2018. Available online: https://psa.gov.ph/sites/default/files/CerPrSitAprWeek32017.pdf (accessed on 28 April 2018).

27. XE Corporation. XE Currency Converter. 2019. Available online: https://www.xe.com/ (accessed on 4 April 2019).

28. SimaPro, Version 8.0.5.13; LCA Software: Amersfoot, The Netherlands, 2017.

29. Ecoinvent. Implementation of Ecoinvent 3. 2017. Available online: http://www.ecoinvent.org/partners/resellers/ implementation-of-ecoinvent-3/implementation-of-ecoinvent-3.html (accessed on 3 December 2017).

30. Bowers, W. Agricultural Field equipment. In Energy in Farm Production; Fluck, R.C., Ed.; Energy in World Agriculture: New York, NY, USA, 1992. 
31. Richard, C.F. Energy Analysis for Agricultural Systems. In Energy in Farm Production; Fluck, R.C., Ed.; Energy in World Agriculture: New York, NY, USA, 1992.

32. IPCC. Emissions Factor Database. 2013. Available online: http://www.ghgprotocol.org/Third-PartyDatabases/IPCC-Emissions-Factor-Database (accessed on 3 December 2017).

33. Dalgaard, T.; Halberg, N.; Porter, J.R. A model for fossil energy use in Danish agriculture used to compare organic and conventional farming. Agric. Ecosyst. Environ. 2001, 87, 51-65. [CrossRef]

34. Industry Data 2.0. Industry Data LCA Library. 2017. Available online: https://simapro.com/databases/ industry-data-lca-library/ (accessed on 17 September 2018).

35. American Time Use Survey. Summary MET Values for Occupation. 2018. Available online: https://epi.grants. cancer.gov/physical/MET/atusmet.php?major[]=05\&keywords=\&metval_min=\&metval_max= (accessed on 17 September 2018).

36. Engineering ToolBox. Combustion of Fuels-Carbon Dioxide Emission. 2009. Available online: https: //www.engineeringtoolbox.com/co2-emission-fuels-d_1085.html (accessed on 12 December 2018).

37. Quaschning, V. Specific Carbon Dioxide Emissions of Various Fuels. 2015. Available online: https: //www.volker-quaschning.de/datserv/CO2-spez/index_e.php (accessed on 20 December 2018).

38. Milne, G. Embodied Energy. 2013. Available online: http://www.yourhome.gov.au/materials/embodiedenergy (accessed on 12 December 2018).

39. Department of Labor and Employment (DOLE). Summary of Current Regional Daily Minimum Wage Rates Non-Agriculture, Agriculture (As of April 2018). Available online: http://nwpc.dole.gov.ph/pages/statistics/ stat_current_regional.html (accessed on 28 May 2018).

40. Hayashi, K.; Ono, K.; Kajiura, M.; Sudo, S.; Yonemura, S.; Fushimi, A.; Saitoh, K.; Fujitani, Y.; Tanabe, K. Trace gas and particle emissions from open burning of three cereal crop residues: Increase in residue moistness enhances emissions of carbon monoxide, methane, and particulate organic carbon. Atmos. Environ. 2014, 95, 36-44. [CrossRef]

41. Arai, H.; Hosen, Y.; Pham Hong, V.N.; Thi, N.T.; Huu, C.N.; Inubushi, K. Greenhouse gas emissions from rice straw burning and straw-mushroom cultivation in a triple rice cropping system in the Mekong Delta. Soil Sci. Plant Nutr. 2015, 61, 719-735. [CrossRef]

42. IPCC. IPCC, methane and nitrous oxide emission factors. In IPCC Guidelines for National Greenhouse Gas Inventories; Eggleston, H.S., Buendia, L., Miwa, K., Ngara, T., Tanabe, K., Eds.; IGES: Kanagawa, Japan, 2006.

43. Kadam, M.P.; Patil, Y.D. The Effect of sieved Coal Bottom Ash as a Sand Substitute on the Properties of Concrete with Percentage Variation in Cement. Am. J. Civ. Eng. Archit. 2014, 2, 160-166. [CrossRef]

44. D'Souza, R.G. Replacement of Fine Aggregate with Bottom Ash in Concrete and Investigation on Compressive Strength. Int. J. Eng. Res. 2017, 6, 172-176. [CrossRef]

45. Detwiler, R.J. Substitution of Fly Ash for Cement or Aggregate in Concrete: Strength Development and Suppression of ASR, RD127; Portland Cement Association: Skokie, IL, USA, 2002. [CrossRef]

46. Pavlík, Z.; Keppert, M.; Pavlíková, M.; Volfová, P.; Černý, R. Application of MSWI bottom ash as alternative aggregate in cement mortar. WIT Trans. Ecol. Environ. 2011, 148, 335-342. [CrossRef]

47. Jenkins, B.M.; Baxter, L.L.; Miles, T.R.; Miles, T.R. Combustion properties of biomass. Fuel Process. Technol. 1998, 54, 17-46. [CrossRef]

48. Topno, S.E. Environmental Performance and Energy Recoverable from Stored Rice Straw Bales in Humid Climate. Ph.D. Thesis, University of the Philippines Los Baños, Laguna, Philippines, 2015.

49. Pishgar-Komleh, S.H.; Sefeedpari, P.; Rafiee, S. Energy and economic analysis of rice production under different farm levels in Guilan province of Iran. Energy 2011, 36, 5824-5831. [CrossRef]

50. Meralco. Rates Archives, 2018. Available online: https://meralcomain.s3.ap-southeast-1.amazonaws.com/ 2018-05/052018_summaryschedule.pdf?null (accessed on 20 May 2018).

51. Department of Energy (DOE). Energy Supply and Demand Outlook. Available online: https://www.doe.gov. ph/energy-supply-and-demand-outlook (accessed on 11 April 2017).

52. Kargbo, F.; Xing, J.; Zhang, Y. Property Analysis and Pretreatment of Rice Straw for Energy Use in Grain Drying: A Review. Agric. Biol. J. North Am. 2010, 1, 195-200. [CrossRef]

53. van Loo, S.; Koppejan, J. The Handbook of Biomass Combustion and Co-Firing; Earthscan: London, UK, 2012. [CrossRef]

54. Tian, X.; Zhang, H.; Sheng, C. Self-Heating of Agricultural Residues during Storage and Its Impact on Fuel Properties. Energy Fuels 2018, 32, 4227-4236. [CrossRef] 
55. Han, M.Y.; Chen, G.Q.; Shao, L.; Li, J.S.; Alsaedi, A.; Ahmad, B.; Guo, S.; Jiang, M.M.; Ji, X. Embodied energy consumption of building construction engineering: Case study in E-town, Beijing. Energy Build. 2013, 64, 62-72. [CrossRef]

56. Koezjakov, A.; Urge-Vorsatz, D.; Crijns-Graus, W.; van den Broek, M. The relationship between operational energy demand and embodied energy in Dutch residential buildings. Energy Build. 2018, 165, 233-245. [CrossRef]

57. Suzuki, M.; Oka, T.; Okada, K. The estimation of energy consumption and CO2 emission due to housing construction in Japan. Energy Build. 1995, 22, 165-169. [CrossRef]

58. Röck, M.; Saade, M.R.M.; Balouktsi, M.; Rasmussen, F.N.; Birgisdottir, H.; Frischknecht, R.; Habert, G.; Lützkendorf, T.; Passer, A. Embodied GHG emissions of buildings-The hidden challenge for effective climate change mitigation. Appl. Energy 2020, 258, 114107. [CrossRef]

59. Aghaalikhani, M.; Kazemi-Poshtmasari, H.; Habibzadeh, F. Energy use pattern in rice production: A case study from Mazandaran province, Iran. Energy Convers. Manag. 2013, 69, 157-162. [CrossRef]

60. Delivand, M.K.; Barz, M.; Gheewala, S.H.; Sajjakulnukit, B. Economic feasibility assessment of rice straw utilization for electricity generating through combustion in Thailand. Appl. Energy 2011, 88, 3651-3658. [CrossRef]

61. Martinez, R.C.; Flores, E.D.; Asuncion, N.T.; Daquila, R.E.; Viloria, W.Z.; Manalabe, R.E. Development of Philmech rice hull-fed furnace system for heating mechanical dryers. PhilMech J. Post Harvest. Eng. 2010, 1, $1-20$.

62. IRRI Knowledge Bank. Economic Aspects of Drying. 1994. Available online: http://www.knowledgebank.irri. org/step-by-step-production/postharvest/drying/economic-aspects-of-drying (accessed on 7 November 2019).

63. Matsumura, Y.; Minowa, T.; Yamamoto, H. Amount, availability, and potential use of rice straw (agricultural residue) biomass as an energy resource in Japan. Biomass Bioenergy 2005, 29, 347-354. [CrossRef]

64. Ishii, K.; Furuichi, T.; Fujiyama, A.; Watanabe, S. Logistics cost analysis of rice straw pellets for feasible production capacity and spatial scale in heat utilization systems: A case study in Nanporo town, Hokkaido, Japan. Biomass Bioenergy 2016, 94, 155-166. [CrossRef]

(C) 2020 by the authors. Licensee MDPI, Basel, Switzerland. This article is an open access article distributed under the terms and conditions of the Creative Commons Attribution (CC BY) license (http://creativecommons.org/licenses/by/4.0/). 